УДК 664.72

(C) 2017

Арендаренко В. М., кандидат технічних наук, Іванов О. М., кандидат технічних наук

Полтавська державна аграрна академія

\title{
ГВИНТОВА ШЛІФУВАЛЬНО-ПОЛІРУВАЛЬНА МАШИНА ДЛЯ ПОВЕРХНЕВОЇ ОБРОБКИ ЗЕРНА БОБОВИХ КУЛЬТУР
}

\author{
Рецензент - кандидат технічних наук В. І. Левчук
}

Наведений описовий огляд конструкиії та приничиnу дії гвинтової иліфувально-полірувальної машини для поверхневої обробки зерна бобових культур, щуо забезпечує підвищення якості обробки поверхні та доведення зерна до однакових геометричних форм та чистоти поверхні. Сформована функціональна залежність між величиною продуктивності технологічної машини та його основними кінематичногеометричними параметрами. В ході покрокового алгоритму були виведені аналітичні формули для масової, об'ємної та поштучної продуктивності гвинтової шліфувально-полірувальної машини.

Ключові слова: продуктивність, зерно, горох, поверхнева обробка, гвинтова канавка, шліфувально-полірувальна машина, барабан, геометричні параметри.

Постановка проблеми. Впровадження міжнародних стандартів та норм якості на харчові продукти вимагає переоснащення вітчизняних переробних підприємств на більш сучасне та енергоефективне технологічне обладнання для випуску продукції, яка б відповідала введеним стандартам. Вітчизняна номенклатура технологічного обладнання для круп'яного виробництва, зокрема механічні засоби поверхневої обробки зерна, не дає змоги дотримуватись норм як по енергоефективності, так і за показниками якості вихідної продукції. Для доведення рівня технічної оснащеності підприємств круп'яного виробництва до сучасного рівня необхідне вдосконалення технологічного обладнання з більш енергоефективним та якісним процесом поверхневої обробки зерна бобових культур.

Аналіз останніх досліджень і публікацій, у яких започатковано розв'язання проблеми. На даний час існує достатньо широка номенклатура машин [1-3] для поверхневої обробки зерна різного як за конструктивними особливостями будови, так і за принципом функціонування та способом впливу на поверхню оброблювального матеріалу. Найбільшої популярності набули технологічні машини [1], в яких процес поверхневої обробки здійснюється в два етапи: спочатку зер- новий матеріал піддається лущенню, за рахунок ударної деформації об жорсткі поверхні, а потім внаслідок тертя об абразивні поверхні робочих органів.

Всі ці машини мають суттєвий недолік, а саме: вони не здійснюють індивідуальну обробку кожного зерна окремо $з$ доведенням їхньої поверхні до відполірованого стану, внаслідок чого товарний вигляд погіршується, знижується харчова та технологічна якість кінцевого продукту.

Метою роботи $є$ наведення детального огляду запатентованої технологічної машини для шліфування та полірування зерна бобових культур, яка дасть змогу підвищувати якість поверхневої обробки зерна бобових культур та доведення їх до однакових геометричних форм та чистоти поверхні.

До завдань дослідження входить висвітлення основних моментів щодо конструктивних та функціональних параметрів роботи, зокрема визначення масової продуктивності, гвинтової шліфувально-полірувальної машини.

Результати дослідження. Гвинтова шліфувально-полірувальна машина (див. рис.) складається із нерухомої станини 1 , корпусу 2 , завантажувального 3 і вивантажувального 4 патрубків. Завантажувальний патрубок оснащений спеціальними кільцями 5 і 6 різного діаметру $\mathrm{d}_{1}>\mathrm{d}_{2}$. В корпусі 2 машини співвісно розміщений горизонтальний барабан 7 з гвинтовою нарізкою та абразивною поверхнею 8. Навколо горизонтального барабану встановлений циліндричний ситовий барабан 9, оснащений всередині по всьому периметрі щітковими циліндрами 10 з можливістю обертання навколо своїх осей. Для видалення лузги і мучки машина оснащена каналом 11 для подачі повітря і вивідним каналом 12, зв'язаним 3 аспіраційною системою. Продувка повітрям внутрішнього простору корпусу 2 здійснюється через радіальні канали 13. Привід валу 7 здійснюється від електродвигуна 14 через гнучкий кінематичний зв'язок 15 [4]. 
Машина працює таким чином:

Попередньо очищене та відкаліброване за розміром зерно бобових культур надходить до завантажувального патрубка 3 , де під власною вагою проходить через отвір діаметра $d_{1}$ кільця 5 , і потрапляє в конусний простір між кільцями 5 i 6 і знову під власною вагою та незначною вібрацією поштучно проходить через діаметр $d_{2}$ кільця 6 і потрапляє у гвинтову канавку валу 7. Вал через кінематичний зв'язок 15 приводиться від двигуна 14 в обертовий рух, під дією чого зерно, рухаючись та обертаючись у гвинтовій канавці в повздовжньому напрямку всередині корпусу 2 між патрубками 3, 4, піддається механічний обробці у випадку різних кінематичносилових умов за рахунок тертя об абразивну поверхню 8 гвинтової канавки горизонтального валу 7 та багатократної дотичної дії щіткових циліндрів 10 на всьому шляху свого переміщення. 3 поступовим наближенням до вивантажувального патрубка 4 поверхня зерна бобових культур набуває однорідного стану та чистоти.

Продуктивність гвинтової шліфувальнополірувальної машини можна представити у вигляді наступної функціональної залежності:

$$
Q=f(n, i, a, b, \beta, \gamma),
$$

де $n$ - частота обертання електродвигуна;

$i$ - передаточне відношення від електродвигуна до валу; $a$ - ширина робочої канавки гвинтової лінії;

$b$ - висота робочої канавки гвинтової лінії;

$\beta$ - кут нахилу гвинтової лінї;

$\gamma$ - коефіцієнт заповнення горохом одного витка гвинтової канавки.

Для виведення аналітичної формули даної залежності представимо, спочатку, продуктивність машини у вигляді класичної формули, а саме як зміщення елементарного об'єму зернової маси у часі уздовж барабану в його осьовому напрямку:

$$
Q=\frac{V}{\tau},
$$

де $V$ - величина елементарного об'єму зернової маси;

$\tau$ - час переміщення елементарного об'єму зернової маси.

За величину елементарного об'єму приймемо об'єм зерна, що знаходиться у гвинтовій канавці та припадає на один піi виток.

Об'єм одного витка гвинтової канавки можна визначити наступним чином:

$$
V=a \cdot b \cdot \ell \cdot \gamma
$$

де $\ell$ - довжина одного витка гвинтової лініі, $\ell=\pi \cdot d_{\text {в }} \cdot \cos \beta$;

$d_{b}-$ внутрішній діаметр гвинтової канавки.
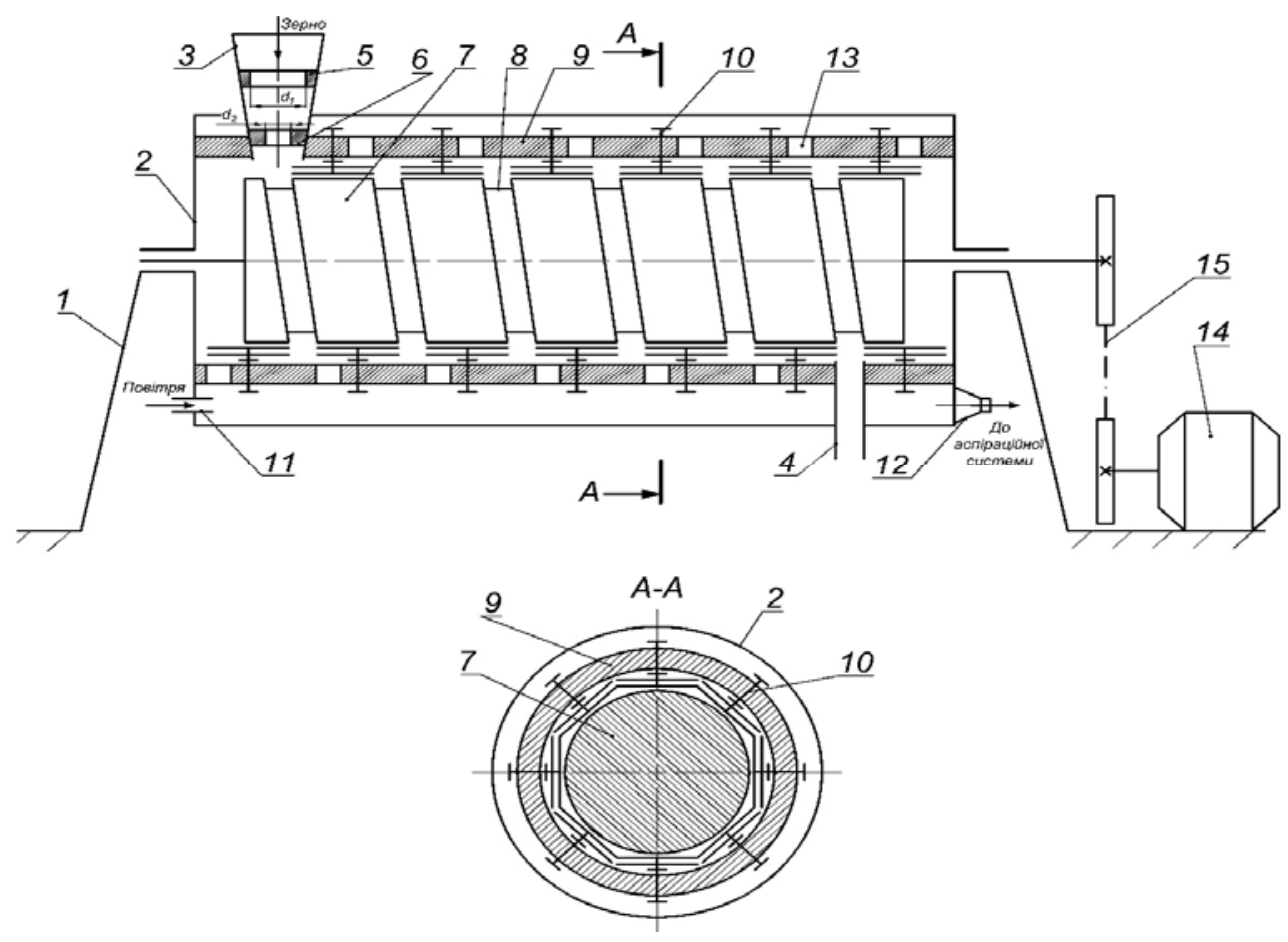

Рисунок. Шліфувально-полірувальна машина 
Експериментальними дослідженнями встановлено, що ширина $(a)$ і висота $(b)$ гвинтової канавки для такого продукту як горох залежить від його середніх розмірів, а також обумовлюються потребою вільного руху без заклинювання у замкненому просторі. Тому геометричні розміри канавки приймаємо, виходячи з наступних залежностей:

$$
\begin{aligned}
& a=(1.1 \ldots 1.2) \cdot d_{2}, \\
& b=0.5 \cdot\left(d_{2}+d_{6}\right),
\end{aligned}
$$

де $d_{2}$ - середній діаметр відкаліброваного за розміром насіння гороху.

Підставивши $a$ i $b$ в формулу (3), отримаємо:

$$
V=k \cdot \pi \cdot d_{2} \cdot\left(d_{2}+d_{B}\right) \cdot d_{B} \cdot \gamma \cdot \cos \beta
$$

де $k=(0,55 \ldots 0,6)$ - коефіцієнт, що враховує неоднорідність геометричних розмірів насіння бобових культур.

Час переміщення елементарного об'єму $V$, що відповідає тривалості переміщення елементарної точки гвинтовій лінії на один іiї оберт, зворотно пропорційний частоті обертання барабану:

$$
\tau=\frac{60}{n_{\sigma}}
$$

де $n_{6}$ - частота обертання барабану, $\mathrm{xв}^{-1}$.

Знаючи передаточне відношення гнучкого кінематичного зв'язку $(i)$ і частоту обертання ротора

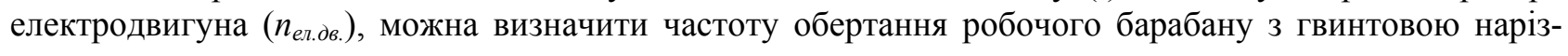
кою:

$$
n_{\sigma}=\frac{n_{\text {ел.дв }}}{i} .
$$

Із врахуванням формул (6-8) година продуктивності гвинтової шліфувально-полірувальної машини буде визначатись із наступного виразу:

$$
V=\frac{60 \cdot k \cdot \pi \cdot d_{2} \cdot\left(d_{2}+d_{B}\right) \cdot d_{B} \cdot \gamma \cdot n_{\text {ел.дв }} \cdot \cos \beta}{i} .
$$

Так як, машина дає змогу здійснювати поштучну обробку зерна бобових культур (наприклад, гороху), то доцільно визначати не тільки загальну продуктивність, а продуктивність по кількості зернин, що обробляються.

Поштучна продуктивність може бути виведена із залежності:

$$
Q_{\text {um }}=\frac{Q}{V_{\text {горох }}},
$$

де $V_{\text {горох }}$ - середній об'єм однієї горошини.

Якщо спростити геометричну форму гороху, то можна представити його як кулеподібне тіло, об'єм якого розраховується:

$$
V_{\text {горох }}=\frac{4}{3} \cdot \pi \cdot r_{2}^{3}=\frac{\pi d_{2}^{3}}{6} .
$$

Знаючи об'єм однієї горошини і загальну об'ємну продуктивність, поштучна продуктивність буде визначатись:

$$
V=\frac{360 \cdot k \cdot\left(d_{2}+d_{b}\right) \cdot d_{b} \cdot \gamma \cdot n_{\text {ел.дв }} \cdot \cos \beta}{i \cdot d_{2}^{2}},
$$

Із використанням формули (12) може бути знайдена і масова продуктивність гвинтової шліфувально-полірувальної машини:

$$
V=\frac{360 \cdot k \cdot\left(d_{2}+d_{B}\right) \cdot m_{2} \cdot d_{B} \cdot \gamma \cdot n_{\text {ел.дв }} \cdot \cos \beta}{i \cdot d_{2}^{2}},
$$

де $m_{2}-$ середня маса однієї горошини, г. 


\section{TEХНІЧНI НАУКИ}

Висновок. Таким чином, у випадку використання шліфувально-полірувальної машини 3 набором щіткових циліндрів та валу 3 нарізаною гвинтовою канавкою 3 абразивною поверхнею дає змогу поштучно обробляти зерно бобових

\section{БІБЛІОГРАФІЯ}

1. A.c. SU 1639738 A1, кл. МПК5 В02B 3/02. Шелушильно-шлифовальная машина / И. Р. Дударев, Л. И. Гросул, И. В. Настагунин, Г. А. Глобенко ; собственник : Одесский технологический институт пищевой промышленности им. В. И. Ломоносова / 4676247/13 ; заявл. 11.04.1991 ; опубл. 11.04.2089, бюл. № 13.

2. Деклараційний патент України на винахід UA 61713А, кл. В02B 3/02 (2006.01). Лущильношліфувальна машина для зерна / Ліпнягов П. П., Мартинов С. О., Ушкаренко В. О., Шевченко П. І., Дударєв I. Р., Ліпнягов М. П., Дударєв I. I. ; заявник $\mathrm{i}$ патентовласник Товариство 3 обмеженою відповідальністю «ВЕЛЕС» 2003042866 ; заявл. 02.04.2003 ; опубл. 17.11.2003, бюл. № 11/2003. культур по всій його поверхні, що сприяє поліпшенню якості та однорідності геометричної форми та чистоти поверхонь зерна, а продуктивність іiі залежить від геометричних і кінематичних параметрів машини.

3. Патент на изобретение RU 2159679, кл. B02B3/02. Шелушильно-шлифовальная машина / Иванов Н. М. / собственник Закрытое акционерное общество научно-производственное предприятие фирма «ВОСХОД» 99112348/13 ; заявл. 11.06.1999 ; опубл. 27.11.2000.

4. Патент України на корисну модель UA 110817, кл. В02В 3/10 (2006.01). Шліфувальнополірувальна машина / Арендаренко В. М. (UA); Іванов О. М. (UA) ; заявник і патентовласники Арендаренко В. М. (UA), Іванов О. М. (UA u201603422 ; заявл. 04.04.2016 ; опубл. 25.10.2016, бюл. № 20. 